\title{
LANGUAGE POWER: VIOLATING THE MAXIM OF QUALITY TO ACHIEVE GOOD COMMUNICATION AND TO KEEP CREDIBILITY
}

\author{
Adi Yusuf ${ }^{1}$, Binti Qani'ah ${ }^{2}$ \\ ${ }^{1-2}$ Universitas Pesantren Tinggi Darul Ulum (Unipdu Jombang) \\ adiyusuf@fbs.unipdu.ac.id
}

\begin{abstract}
One of various aspects to a series of activities on successful business is really influenced by the appropriate use of language. Public Relations (PR) people, in order to make good communication with their business partners, indeed need to have good understanding on language uses so that the business activities are successful. One of the language uses can be identified through the principle of communication, called "maxims". The purpose of this paper is to describe the use of language and contexts which lead us to violate the maxim of quality. This research used a descriptive qualitative method. It was found that language may be used as a means to achieve enormous influence in a series of marketing campaign. In addition, in line with the use of 'the maxim of quality', low power public relations in a certain situation need to violate it in order to achieve good communication and to make business activities successful at last. Furthermore, "a white lie" or "no comment" may become an alternative way to make the hearer pleased and to save one's credibility.
\end{abstract}

Keywords: language power, enormous influence, violating the maxim of 'quality', good communication, credibility.

Abstrak: Penggunaan bahasa yang tepat merupakan salah satu aspek yang dapat mempengaruhi suksesnya serangkaian kegiatan dalam bisnis. Para staff bagian personalia perlu memiliki pemahaman yang baik tentang penggunaan bahasa untuk menciptakan sebuah komunikasi yang baik dengan rekan bisnis supaya kegiatan bisnis tersebut berjalan dengan lancar. Salah satu penggunaan bahasa dapat diketahui melalui prinsip komunikasi yang disebut "maxims". Artikel ini bertujuan untuk mendeskripsikan penggunaan bahasa dan konteks kapan seharusnya menggunakan atau melanggar maxim of quality. Metode penelitian ini ialah deskriptif kualitatif. Dari hasil penelitian ditemukan bahwa bahasa dapat digunakan sebagai alat untuk memperoleh pengaruh yang luar biasa dalam serangkaian kampanye pemasaran. Di samping itu, berkenaan dengan penggunaan maxim 'quality', humas dengan posisi lebih rendah, pada situasi tertentu, perlu melanggar maxim tersebut agar tercipta komunikasi yang baik dan akhirnya kegiatan bisnis berhasil. Selanjutnya, "a white lie" atau "no comment" bisa menjadi salah satu cara untuk membuat pendengar senang dan menjaga kredibilitas.

Kata Kunci: kekuatan bahasa, pengaruh yang luar biasa, melanggar 'the maxim of quality', komunikasi yang baik, kredibilitas.

\section{INTRODUCTION}

Language, in a series of activities in business negotiation, really has its own power. Power refers to "the ability to influence others to do things they would not do otherwise" (Bacharach and Lawler, 1981; Molm, Peterson and Takahashi, 1999 cited in Knippenberg and Hogg, 2003, p. 154). One of various aspects to the success of negotiation is really influenced by the appropriate use of language. Public Relations (PR), in order to make good communication with their business partners, indeed need to have good understanding on language uses so that the business activities are successful. 
One of the language uses can be identified through the principle of communication, called "maxims" as proposed by Grice (1989).

In our daily life, the rule or principle of communicating with other people and conveying our ideas are often based on maxims. According to Grice (1989) cited in Fromkin et al. (2011), there are four kinds of conversational maxims: (1). Quantity: "Say neither more nor less than the discourse requires.", (2). Relevance: "Be relevant.", (3). Manner: "Be brief and orderly; avoid ambiguity and obscurity.", and (4). Quality: "Do not lie; do not make unsupported claims" (p.213).

The use of the maxims above is indeed necessary to make a good relationship among our relations and to have a good effect of ideas we convey. Whether people are interested in responding any utterance or not may depend on how we apply the maxims. For instance, the Pepsi-Cola company saw its slogan, "Come alive with Pepsi!" literally translated into Mandarin Chinese could mean, "Pepsi brings your ancestors back from the dead!" - "Pepsi revives your dead ancestors!" The slogan stops in a short time (Wilcox, et al. 2006, p. 108). Besides the problem of image in China, the cause of nonexistent slogan may be the violation of the maxim of quality; one does not try to be truthful. In line with the maxim of quality, Cutting (2002) notes that "speakers are expected to be sincere, to be saying something that they believe corresponds to reality. They are assumed not to say anything that they believe to be false or anything for which they lack evidence"(p.35).

However, good public relations people need to understand well not only when to use the maxim but also when to avoid it when communicating with clients. The appropriate situation to use or violate it needs to be considered in order that a series of negotiation runs smoothly. This paper would like to discuss the power of language, more specifically the language use as a means to get enormous influence and a certain time situation causing public relations people to violate the maxim 'quality' in a series of business negotiation. It is expected that the result of this paper give contribution to the study of applied linguistics and public relations.

\section{METHOD}

This research was conducted qualitatively. This study aimed at describing a theory on pragmatics. The data were taken from related sources containing sentences or statements, and advice from experts in the form of words or sentences related to language use based on contexts. The technique for collecting the data was quoting some statements and sentences from some books. The data were then analyzed by relating the data to the theory to know the power of language and contexts when to violate the maxim of quality. According to Sutopo (2006) qualitative data are in the form of words, sentences or pictures which are meaningful and lead to more evident understanding rather than numbers and frequencies (p.40).

\section{RESULT}

It was found that there were 4 data. The first data containing an example of campaign of Japan Automobile Manufacturers Association using advertisement which showed that language has power which can be used as a means to seek enormous influence. The second data also contains an example of two executive men sent to Malaysia by an aircraft manufacturer to offer domestic-made aircraft which indicates when to violate the maxim of quality. Next, a statement from an expert "a white lie" also describes a 
context when to violate the maxim. The last, the expression of "no comment" was advice from experts may also indicates that language may be used to keep credibility. These findings are discussed more below.

\section{DISCUSSION}

\section{Language Power - A Means To Achieve Enormous Influence}

In business negotiation, language has a great power to communicate a message and to achieve people's belief. It is commonly used by Public Relations (PR) to deliver a message which then finally aims to influence people. A specialist of veteran Public Relations (PR), Robert L. Dilenschneder regards PR as "the art of influence". He claims that the sources of power are "remembering and using the linkage of communication, recognition and influence..." He adds that, in the vernacular of creative advertising people, PR refers to "giving the pubic permission to believe". If a message delivered has quality, people are willing to accept it; what they need is just a reason (Marconi, 2004, p.24).

In many situations, PR people are "second only to the CEO as 'face' or 'voice' of an organization to its most constituent groups. Furthermore, as the people who are in charge of front line contacts, they have responsibilities, such as answering questions, getting comments, and being "a critical source of information" to whatever the public think or say about the organization. "He or she has an open line to those that management seeks to influence, and it is a line that must be managed with care" (Marconi, 2004, p.25). This explanation on the tasks of PR can be concluded that as professional PR, he or she undoubtedly has a hard job i.e. seeking influence. This task may be achieved through the appropriate use of language in fulfilling these responsibilities.

Data 1 an example of language used as a means to seek enormous influence can be seen in the following campaign of Japan Automobile Manufacturers Association. The example of language power may be reflected by the use of language the following series activities conducted by Public Relations (PR), they are in campaign, advertisements, and an interview as exemplified by Wilcox et al as follows. The example of Public Relations (PR) campaign was conducted by Japan Automobile Manufacturers Association, during 1980's, to overcome the increase of American people's sentiment towards the limitation of imported-automobile sales. This campaign was started with a series of advertisements contained in a full one page found in popular newspapers in the United States. The advertisements contained an interview with American economists and a group of consumers that supported automobile imports and free-trade policy. The title of the advertisement was "In the Consumer's Interest, Dialogues on the Open Market for Automobiles". One of the Japan Automobile Manufacturers stated "we want to start communicating with American people". Serious attention to the American people's opinion was also represented in the next decision to make some Japanese automobiles in America, with American workers (Wilcox, et al. 2006, p.126).

Another example indicating that language may contribute to enormous influence can be clearly seen in the following phenomenon. The Executive of Chevrolet never realized why Chevy Nova was not marketable in Latin America. Finally, they knew that although the word 'Nova' means 'new' in Spanish, it actually has a negative meaning 'does not work' (Wilcox, et al. 2006, p.109). The use of language in this phenomenon shows that language indeed has the power in business. A word may have a positive 
meaning in a language, but it may have a negative meaning in another language. In this example, we can see how a language used by The Executive of Chevrolet could not attract the Latin American.

In sum, the description on language power; how language is used to seek influence and to make good communication, and when it is erroneously used as a result of cross-cultural understanding above reveals that language is active, instead of passive. This view is widely shared; as Knippenberg and Hogg (2003) state that language indeed provides an active channel for the exercise of power and influence; it is "an active coplayer in social action". The power of language shows this active contribution of language to power. "To create material power, to conceal or mask the exercise of power" we can use language. However, when it is felt as undesirable, and it can help us to make "a dominance relationship appear natural"(p.212).

\section{Language Power - Violating The Maxim Of 'Quality' To Achieve Good Communication And To Keep Credibility}

The above example indicates that language really has the power to influence others in business. Besides, there is a crucial aspect in relation to the use of language; the rule of communication that generally many people use, commonly called 'maxims'. However, in certain situation such as in a series of activities of negotiation we sometimes need to consider the appropriate situation to use the maxim, otherwise the partners may get offended that finally does not result in a good business deal.

The appropriate situation of using maxims needs to be considered well. In our daily life, we frequently need to use the four sub-principles (called maxims) when communicating with other people. One of the examples, According to Grice (1975 in Palmer, 1981) cited in Adisutrisno (2008), is the use of the maxim of quality: "try to make your contribution one that is true, i.e. do not say what you believe to be false"(p.72). This part of a cooperative principle of conversation means we have to make our statement true. There is an important thing to notice here, that is the word 'true'. Saying something that is true (telling the truth) is one of proofs that language use has great power and is really required in our daily interaction to others since it may indicate that the speaker is believable and means that the hearer is not being tricked. The example of the appropriate use of this maxim can be seen as the following conversation:

A : "I'll ring you tomorrow afternoon then.

B : Erm, I shall be there as far as I know, and in the meantime have a word with Mum and Dad if they're free. Right, bye-bye then sweetheart.

A : Bye-bye, bye" (BNC: kc8 Gillian, 1991 cited in Cutting, 2002, p.35).

The expression of "as far as I know" here indicates that the speaker B was uncertain and was "protected from accusations of lying ... Most hearers assume that speakers are not lying, and most speakers know that".

Conversely, telling the truth is not always necessary and it does not always have a good effect in our daily interaction. We have to see the contex and consider 'attitude' carefully. There is an interesting example made by Agustian (2003) in his book ESQ POWER that needs to be considered. Below is the example of the story (data 2).

One day, there were two executive men sent to Malaysia by an aircraft manufacturer to offer domestic-made aircraft. They finally were accepted by the CEO (Chief Executive Officer) of the largest oil companies in Malaysia as the guest of honor. The two executives were invited to have dinner at the residence of the CEO. After 
dinner, the two executives were invited by the CEO to see his antique collections. The CEO proudly explained the collections. The executives listened carefully any explanation given by the CEO. They certainly nodded agreeably with the expression of admiration, but they like the antiques or not is not known.

Finally, the CEO, prospective clients of aircraft buyers asked one of the Indonesian executives (incidentally, the one who is asked is a scholar of postgraduate (S2) in the field of flight). He asked, "What do you think of my collections? ', Smiling proudly, the executive blurted, "In my opinion, this collection of antiques is good, but at Surabaya street, there are many antiques like this and they are cheap, sir." After hearing the answer of the executive, the CEO was offended and finally decided not to buy the aircraft (Agustisn, 2003, pp.61-62).

The story above shows us that besides the factor of mental dimension (EQ), the use of "the maxim of quality: try to make your contribution one that is true" as proposed by Grice (1975) needs considering. From the point of view, the executive's answer is true, he tells the fact that the antiques are easily found in Surabaya street and the price is really cheap. However, in this contex, telling the truth should be avoided in oder that the hearer (CEO) feels glad. The result of the answer certainly makes the hearer offended and of course, the effect of the offering is not as being expected, i.e. the CEO as prospective clients of aircraft buyers refuse it.

Based on the description above, it can be assumed that the executive also neglects the 'power rating' or Brown and Levinson (1987) cited in Rahardi (2005) called 'the speaker and hearer relative the speaker which is based on the 'asimetrik' level between the speaker and hearer'(p.69). He is apparently not able to consider his own level or position and the level of the client or listener. This can be seen in the way of communicating; he does not think that he should not say something that makes the listener offended. As an executive, especially when his task is to offer the product, he should be aware that his position is lower than the client as a buyer. In this context the two executive men that were sent to Malaysia should have realized that they had low power since they were assigned to offer the product; they should have pleased the CEO. In relation to this phenomenon, it will be better to apply a theory on low position behavior towards more powerful opponents as suggested by Knippenberg and Hogg (2003) that "Low power negotiators are motivated to pay close attention to their powerful opponent, and to please him or her, while those with high power are more likely to operate on the basis of their own instead of the opponent's wishes and demands"(p.166).

In line with the position of the two executives as the public relations, it would be better if they behave carefully or if necessary they have a motto of "caveat venditor". Bertens (2013) points out that the seller should use the motto which means that the seller must be careful. Producers of any product must be responsible for any disadvantages suffered by consumers that use the product. In such position, the seller should not use the motto mentioned in the proverb of old Rome "caveat emptor" which means the buyers should be careful. This motto would be more appropriate if it is applied from the perspective of contracts (pp. 254-257).

The phenomenon above clearly teaches us to be aware of the right situation to use maxims. In the above contex, it would be better to break the rule or maxims. It is necessary not to make the contribution one that is true. In this case, the writers suggest that the two executives as negotiators of the aircraft manufacturer use "integrating tactics" proposed by Solihin in his book Pengantar Bisnis. He claims that those who 
seek influences may make use human's need of this tactic as great respect to others that need to be respected. Besides, those who seek influences by applying this tactic frequently present a variety of facts that want to be known by their higher authority, instead of real facts. This integrating tactic may cause those who integrate to look competent at their job and finally they may get a great support from their higher authority. For example, some mayors in Indonesia never give any prediction of their people who suffer from malnutrition in their district. A report indicating the possibility of such malnutrition will definitely decrease their credibility as mayors to a President (Solihin, 2014, p. 153).

This tactic, certainly, has a close relationship to the theory on leadership. However, it can be applied by any public relations people as it is mainly purposed to attract their higher authority's attention in order that the negotiation runs well. Even, if necessary the speaker complements the listener, for example, by saying that the antiques are really wonderful and they must be expensive and made with a long and meticulous process. Although this compliment may contradict to the fact that the antiques are cheap, at least the hearer will feel proud and finally he feels convinient of the communication. Then, when the client feels convinient, this automatically has a good effect, the transaction may be able to run well. Furthermore, one important thing is that the CEO above is considered to have 'high power'; he or she is definitely sensitive, as noted by Lee and Tiedens (2001) cited in Knippenberg and Hogg (2003) that high power individuals tend to be "sensitive", socially skilled, famous, supportive, reliable, helpful, and likeable. High power people are prone to "go out of their way to compliment others", work together with others, be humble and givin, try to persuade others to be in a good mood, and "build relationships and trust".

This phenomenon may also be related to 'affective' too in which it influences someone to be able to use 'feeling' so that he or she will not hurt others' feeling. With 'affective' one will be able to appreciate the others. According to Martin and Briggs (1986) cited in Suciati (2005) 'the purpose of affective is in line with 'feelings', 'emotions', 'system of values' and 'attitudes of the heart' (attitude) that indicates acceptance or rejection of something. Affective goal consists of the simplest, namely 'paying attention to a phenomenon up to the complex which is a person's internal factors, such as personality and conscience'. Therefore, in this context of discussion, it is suggested that public relations people be good at keeping his business partners in good mood. It would be better if he or she always tries to please business partners in order that a good communication can be achieved.

\section{Language Power - A White Lie and "No Comment" As Solutions To Keep Credibility}

It is widely believed that in our daily interaction, Emotional Quotient (EQ) plays an important role to lead someone to use an appropriate language, for example, it is necessary for us to violate the maxim of quality in other words we can say 'tell a lie' in order to show politeness and to please hearers. The above example of complement as the antiques are really wonderful and they must be expensive and made with a long and meticulous process, in other words, might be regarded as a lie from the view of the two executive men, however it might be able to prevent the CEO from being upset rather than being told the truth. In this case "a white lie" may be applied as a solution to make the CEO pleased. 
In relation to EQ in the actions, Cooper and Sawaf (2000) proposed a practical exercise that allows the growth of a deeper understanding on one self. Ask yourself, "if I am responsible for every feeling that I experience and for every word that I say ......," What is your answer? Here is one of the comments from several executives after they practiced it "I will not do or say something that hurts other people anymore" (p.70). This expression clearly indicates that language may contribute to give a significant effect i.e. to keep one's feeling; one will be pleased or upset because of 'every word' that we utter. Thus, to anticipate one's feeling of anger "a white lie" can be a solution to this problem. The following statement stated by Cutting (2002) showed data 3 that a white lie refers to "a lie that protects a lie with good intentions" (p.40).

Finally, data 4 below indicated that "No Comment" may be as a solution to keep credibility. The other solution regarding the use of language may be found in the use of the expression "No comment". This may be applied when a speaker has no choice, for instance, when he or she tells the truth or a lie has a bad effect as the loss of credibility. This view is commonly shared by Wilcox, et al., (2006) that public relations experts advise a speaker who intends to hold a press conference that he or she not lie! If he gets cornered and feel absolutely sure that answering a certain question is unwise, it would be better to say, "No comment" in any way than giving an incorrect answer. A person who is trapped in the untruth in the view of the media must dare to lose credibility in a bitter way (p.352).

\section{CONCLUSION AND SUGGESTION}

Based on the explanation above, it can be noted that language indeed has great power in daily life; it contributes to the success of influencing the public. On the other hand, in the case of language use, the use of maxims is not always certain or fixed. In our daily interaction, we need to consider the right time or situation to use the maxims. There is an occasion when to violate the maxims - it is sometimes necessary to neglect the maxims provided that the effect is good, the hearer is not offended of what we have already said. In addition, breaking the rule of maxims sometimes has the image of aesthetic pleasure as in the context of making the business partner pleased that may trigger to a good relationship and the successful negotiation. Furthermore, "a white lie" or "no comment" may become solutions to make the hearer pleased and to keep one's credibility.

As educators, it is imperative that when teaching students about language use or communication principles, they should not marely focus on transfering knowledge and skill. There is a another crucial thing that needs to be considered that is 'attitude' or 'affective' - considering the effect of utterances. It is also suggested that researchers find other phenomena on when or how to use maxims on the appropriate time so it has a good effect.

This is conducted not to seek the weakness of maxims instead of completing the theory; furthermore it is hoped that the result of this article gives ideas on language power and the use of maxims to readers and triggers them to continue writing on this kind of topic which may also be beneficial to the development of the theory of pragmatics and the theory of public relations. 


\section{REFERENCES}

Adisutrisno, D. W.(2008). Semantics. An Introduction to the basic Concepts. Yogyakarta. Andi.

Agustian, A.G. (2003). ESQ POWER. Jakarta. Arga.

Bacharach, S.B., and Lawler, E.J. 1981. Bargaining. San Fransisco: Jossey-Bass.

Bertens, K. (2013). Pengantar Etika Bisnis. Yogyakarta: Penerbit PT Kanisius.

Brown, Penelope and S.C. Levinson. 1987. 'Universals in Language Usage: Politeness Phenomena', dalam Esther N. Goody (ed.) Questions and Politeness. Cambridge: Cambridge University Press.

Cutting, J. (2002). Pragmatics and Discourse. London: Routledge.

Fromkin, V., Rodman, R., \& Hyams, N. 2011. An Introduction to Language.Ninth Edition. Boston, USA: Wadsworth Cengage Learning.

Grice, H. P. (1989). Logic and conversation. Reprinted in Studies in the way of words. Cambridge, MA: Harvard University Press.

Knippenberg, D.V. and Hogg, M.A. (Eds.) (2003). Leadership and Power: Identity Processes in Groups and Organizations. London: SAGE Publications.

Lee, F. and Tiedens, L.Z. 2001. Is it lonely at the top? The independence of power holders. Research in Organizational Behavior, 23, 43-91.

Marconi, J. (2004). Public Relations. The Complete Guide. USA: Thomson

Martin, B. L. \& Briggs, L. J. (1986). The Affective and Cognitive Domains. New Jersey: Educational Technology Publication.

Molm, L.D., Peterson, G., and Takahashi, N. (1999). Power and negotiated and recriprocal exchange. American Sociological Review, 64, 876-90.

Palmer, F.R. (1981). Semantics. Cambridge: Cambridge University press.

Rahardi, K. (2005). PRAGMATIK. Jakarta: Erlangga.

Solihin, I. (2014). Pengantar Bisnis. Jakarta: Penerbit Erlangga.

Sutopo, H.B. (2006). Metodologi Penelitian Kualitatif. Surakarta: Universitas Sebelas Maret.

Suciati. 2005. Taksonomi Tujuan Instruksional. Jakarta: PAU-PPAI.

Wilcox, D. L., Ault, P. H., \& Agee, W. K. (2006). Public Relations. Strategi dan Taktik. Batam Centre: Interaksara. 